\title{
Yield and quality performance of open pollinated and hybrid tomato cultivars grown under organic management in Puerto Rico, ${ }^{1,2}$
}

\author{
Kevin Brady ${ }^{3}$, Bryan Brunner ${ }^{4}$, José Pablo Morales-Payán ${ }^{5}$ \\ and Sonia Martínez Garrastazú ${ }^{6}$
}

J. Agric. Univ. P.R. 97(3-4):149-170 (2013)

\begin{abstract}
Variety trials were conducted in 2010 and 2011 to evaluate the yield and quality performance of 11 open pollinated and three hybrid tomato (Solanum lycopersicum L.) cultivars grown organically in Lajas, Puerto Rico. In both years, significant differences in marketable fruit yield were observed. Yields in 2010 ranged from $72.1 \mathrm{Mg} / \mathrm{ha}$ for 'Roma' to $8.6 \mathrm{Mg} / \mathrm{ha}$ for 'Marion'. 'Roma' and 'Neptune' $(65.6 \mathrm{Mg} / \mathrm{ha}$ ) were among the highest yielding cultivars. In 2011, significant yield differences were also observed. Marketable fruit yield ranged from $54.7 \mathrm{Mg} / \mathrm{ha}$ for 'Early Girl' to $23.5 \mathrm{Mg} / \mathrm{ha}$ for 'Super Sioux'. 'Early Girl', 'Flora Dade' (53.8 Mg/ha), 'BHN 444' (50.8 Mg/ha), 'Roma' (48.6 Mg/ha), 'Eva Purple Ball' (48.4 Mg/ha), 'Traveler 76' (46.4 Mg/ha) and 'Celebrity' (45.9 $\mathrm{Mg} / \mathrm{ha}$ ) were among the highest yielders. 'Early Girl' was consistently among the top cultivars in both seasons for taste, yield, and fruit appearance. Open pollinated cultivars performed with more variability between the two seasons than the hybrids. The open pollinated cultivars which ranked highest during the two-year study for taste, yield, and overall appearance were 'Roma', 'Homestead 24', 'Ozark Pink', and 'Traveler 76'. This study indicates that tomato can be grown successfully under an organic management system in Puer to Rico using either open pollinated cultivars or hybrids.
\end{abstract}

Key words: tomato, Solanum lycopersicum, organic production, variety trial

\section{RESUMEN}

Rendimiento y calidad de fruta de cultivares de tomate de polinización abierta e híbridos cultivados bajo manejo orgánico en Puerto Rico

${ }^{1}$ Manuscript submitted to Editorial Board 13 September 2013.

${ }^{2}$ This material is based on work supported by the Natural Resources Conservation Service, U.S. Department of Agriculture, under number NRCS 69-F352-09-0; and by Institutional Grant SP-440, "Evaluation of diverse tomato germplasm under organic management".

${ }^{3}$ Former graduate student, Department of Horticulture, University of Puerto Rico, Mayagüez Campus.

${ }^{4}$ Corresponding author. Researcher, Agricultural Experiment Station, HC-02 Box 11656, Lajas, PR 00667. Email: bryan.brunner1@upr.edu

${ }^{5}$ Associate Professor, Department of Crops and Agroenvironmental Sciences, University of Puerto Rico, Mayagüez Campus.

${ }^{6}$ Associate Researcher, Agricultural Experiment Station, HC-02 Box 11656, Lajas, PR 00667. 
Se llevaron a cabo pruebas de variedades con manejo orgánico en Lajas, Puerto Rico, en el 2010 y 2011 para evaluar el rendimiento y la calidad de 11 cultivares de polinización abierta y tres híbridos de tomate (Solanum lycopersicum L.). En ambos años se observaron diferencias significativas para el rendimiento de frutas mercadeables. El rango de rendimiento en el 2010 fue de $72.1 \mathrm{Mg} / \mathrm{ha}$ para 'Roma' a $8.6 \mathrm{Mg} / \mathrm{ha}$ para 'Marion'. 'Roma' y 'Neptune' $(65.6 \mathrm{Mg} / \mathrm{ha}$ ) estuvieron entre los cultivares con mayores rendimientos. En el 2011, el rango en rendimiento fue de $54.7 \mathrm{Mg} / \mathrm{ha}$ para 'Early Girl' a 23.5 Mg/ha para 'Super Sioux'. 'Early Girl', 'Flora Dade' (53.8 Mg/ha), 'BHN 444' (50.8 Mg/ha), 'Roma' (48.6 Mg/ha), 'Eva Purple Ball' (48.4 Mg/ha), 'Traveler 76 ' $(46.4 \mathrm{Mg} / \mathrm{ha}$ ) y 'Celebrity' ( $45.9 \mathrm{Mg} / \mathrm{ha}$ ) estuvieron entre los cultivares con los rendimientos más altos. 'Early Girl' estuvo consistentemente entre los mejores cultivares en los dos años para sabor, rendimiento y apariencia. Los cultivares de polinización abierta presentaron mayor variabilidad entre años que los híbridos. Los mejores cultivares de polinización abierta para sabor, rendimiento y apariencia en los dos años fueron 'Roma', 'Homestead 24', 'Ozark Pink' y 'Traveler 76'. Este estudio indica que se puede cultivar el tomate exitosamente bajo un sistema de manejo orgánico en Puerto Rico usando cultivares de polinización abierta o híbridos.

Palabras clave: tomate, Solanum lycopersicum, producción orgánica, ensayo de variedades

\section{INTRODUCTION}

Local organic vegetable production can be adopted as a strategy for improving food security and environmental protection in Puerto Rico. The island is currently highly dependent on conventionally produced imported foods. Presently, Puerto Rico imports an estimated $82 \%$ of its food (Department of Agriculture of Puerto Rico, 2012). Most of the vegetables sold in Puerto Rico are grown in highly mechanized monocultures with synthetic fertilizers and agrochemicals, and are transported thousands of miles before reaching consumers, which greatly increases the energy requirement and carbon footprint for these perishable products (Hill, 2008). Local organic food systems can help reduce our dependence on imported foods and minimize environmental impact of food production. One of the primary steps toward greater food security in Puerto Rico is to identify and/or develop vegetable varieties that are adapted to organic management systems under tropical conditions, which can be challenging due to year-round high temperatures, excessive rainfall, and high pest, disease and weed pressure. Choosing the right crops and varieties for local agro-ecosystems can significantly minimize crop failure and increase agricultural success (Colley and Myers, 2007).

Tomato (Solanum lycopersicum L.) is the most economically important vegetable grown in Puerto Rico. During the 2008-2009 season, agricultural gross income for tomatoes was 24.4 million dollars (Department of Agriculture of Puerto Rico, 2010). Virtually all of the tomatoes 
produced in Puerto Rico are grown conventionally on the south coast during the dry season. The largest producer on the island is Gargiulo Inc. in Santa Isabel, which produces $17,000 \mathrm{Mg}$ of tomatoes on 243 ha each year (Vetiver Solutions Blog, 2010). Tomatoes are harvested in Puerto Rico from January until the end of March for export to the United States. Peak demand for exported Puerto Rican tomatoes is in January and February when production is low in Florida. Only green tomatoes are exported to the U.S.; any tomatoes with color change are sold in the local market. During the winter season, Puerto Rico imports $40 \%$ of its tomatoes, while the rest of the year $90 \%$ are imported (Almodóvar and Alamo, 1999).

Most of the commercially available vegetable cultivars have been developed and adapted to conventional agricultural systems. These systems are characterized by the use of synthetic chemical inputs, mechanized management practices, and the dependence on an increasingly small number of hybrid varieties for its major crops (Mendum and Glenna, 2010). Furthermore, many genetically engineered (GE) vegetables are currently under various stages of trial and/or commercialization (Sidhu and Chellan, 2010). GE sweet corn, for example, has been grown commercially in the United States since 2012, and was developed to tolerate direct applications of glyphosate herbicide as well as to produce endogenous Cry insecticidal proteins (Seminis, 2013).

Crop cultivars do not perform equally in conventional and organic production systems (Murphy et al., 2007). With some exceptions (i.e., disease and pest resistance), conventional agricultural systems do not have the same selective pressures as organic systems and therefore do not promote the development of optimum genetics for organic production. Also, their use of synthetic agrochemicals and GE varieties does not meet the guidelines of organic farming (Lammerts van Bueren, 2002). It is important to conduct organic variety trials to determine which varieties perform best under organic management. For example, cultivars with traits like deep, extensive root systems or the ability to interact with beneficial soil microorganisms may perform better in an organic system versus a conventional system (Lammerts van Bueren et al., 2010).

The organic farming movement needs new varieties that are bred under low input organic conditions (Lammerts van Bueren et al., 2010). Crop varieties developed under conventional management often lack adaptive traits that are important under organic production systems. For example, organic breeding programs may select crop genotypes that are able to increase nutrient use efficiency, form symbiotic relationships with soil microbes, and be tolerant to disease, insects, and abiotic stresses. These ideal variety characteristics or crop ideotypes 
can provide the genetic materials for the development of improved varieties (Lammerts van Bueren, 2003). Additionally, there is a need to identify adapted vegetable varieties for home gardens that do not require a high level of inputs.

Several researchers at the University of Puerto Rico have conducted tomato variety trials at agricultural experiment stations (AESs) throughout the island. The results have been summarized in several reports (Wessel-Beaver et al., 1990; Fornaris et al., 1991; Colberg-Rivera et al., 1996; Fornaris et al., 2009). These variety trials demonstrate that location, season, and year influence a cultivar's overall performance. Yet, all of these variety trials were managed under a conventional system using synthetic inputs and primarily hybrid varieties. There is a need for information on tomato cultivar performance under organic management in the tropics.

The objective of this research was to evaluate the yield and quality performance of eleven open pollinated tomato cultivars and three hybrids under an organic management system, in order to select superior performing tomato cultivars for local organic tomato production and organic seed production.

\section{MATERIALS AND METHODS}

The variety trials were conducted at the Lajas Substation of the University of Puerto Rico in southwestern Puerto Rico (lat. $18^{\circ} 01^{\prime} \mathrm{N}$, long. $67^{\circ} 04^{\prime} \mathrm{W}$, elevation $27 \mathrm{~m}$ ). The soil series is Fraternidad clay that is very deep, moderately well drained, very slowly permeable and weathered from volcanic rock and limestone (National Cooperative Soil Survey USA, 2006). During the winter/spring seasons, average monthly precipitation ranges from about $5 \mathrm{~cm}$ in January to over 10 $\mathrm{cm}$ in May. Soil tests on site revealed very high levels of potassium, magnesium, calcium, and copper, with very low levels of phosphorous and zinc. Soil pH was 8.2.

Fourteen cultivars were evaluated during the 2010 and 2011 winter/spring season (Table 1). Eleven cultivars were open pollinated and three cultivars were hybrid controls. Half of the cultivars had an indeterminate growth habit and half had a determinate plant type. Cultivars were chosen for their suitability for fresh market organic production, and were all slicing type tomatoes, except for the processing type 'Roma', which is grown locally for the fresh market. The criteria for cultivar selection were as follows: 1) cultivars were open pollinated except for three hybrid controls, 2) high to medium yield levels, 3) fruit of medium size, 4) cultivars with known disease resistances, especially 
TABLE 1.-Tomato cultivars selected for the tropical organic variety trial at the Lajas Experiment Station, Puerto Rico. Characteristics are those reported by seed suppliers.

\begin{tabular}{|c|c|c|c|c|c|c|}
\hline Cultivar (Source) ${ }^{1}$ & $\begin{array}{l}\text { Cultivar type } \\
(\mathrm{OP} / \mathrm{F} 1)^{2}\end{array}$ & $\begin{array}{l}\text { Days to } \\
\text { maturity }\end{array}$ & $\begin{array}{l}\text { Heat } \\
\text { tolerance }\end{array}$ & $\begin{array}{l}\text { Disease resistance } \\
\text { and fruit disorders }\end{array}$ & $\begin{array}{l}\text { Growth } \\
\text { habit }\end{array}$ & $\begin{array}{c}\text { Average } \\
\text { weight }\end{array}$ \\
\hline Ace $55(\mathrm{~V})$ & $\mathrm{OP}$ & 75 & Yes & $F_{w 1}, V_{w}$ & Determinate & $224 \mathrm{~g}$ \\
\hline BHN 444 (T.G.S.) & F1 & 75 & Yes & Fw1, Fw2, Tswv, Vw & Determinate & $224 \mathrm{~g}$ \\
\hline Celebrity (T.G.S.) & $\mathrm{F} 1$ & 70 & Widely Adapted & An, Fw1, Fw2, Gls, Rkn, Tmv, Vw & Determinate & $224 \mathrm{~g}$ \\
\hline Early Girl (T.G.S.) & $\mathrm{F} 1$ & 52 & Widely Adapted & Fw1, Fw2, Vw & Indeterminate & $140 \mathrm{~g}$ \\
\hline Eva Purple Ball (S.E.S.) & OP & 78 & Yes & $\mathrm{Eb}, \mathrm{Lb}$, ber, cr, cf & Indeterminate & $140 \mathrm{~g}$ \\
\hline Flora Dade (V) & $\mathrm{OP}$ & 78 & Yes & Fw1, Fw2, Gls, Vw & Determinate & $196 \mathrm{~g}$ \\
\hline Homestead 24 (S.E.S.) & $\mathrm{OP}$ & 80 & Yes & Asc, Fw1 cf, cr & Determinate & $224 \mathrm{~g}$ \\
\hline Marion (T.G.S.) & $\mathrm{OP}$ & 78 & Yes & $\mathrm{Bs}, \mathrm{Fw} 1$, Gls & Indeterminate & $168 \mathrm{~g}$ \\
\hline Neptune (S.E.S.) & $\mathrm{OP}$ & 67 & Yes & $\mathrm{Bw}, \mathrm{Fw} 1, \mathrm{~F}_{\mathrm{w}} 2, \mathrm{Gl}_{\mathrm{s}}, \mathrm{V}_{w 1}$ & Determinate & $140 \mathrm{~g}$ \\
\hline Ozark Pink (S.E.S.) & $\mathrm{OP}$ & 65 & Yes & Fw1, $V_{w}$ ber, $\mathrm{cr}$ & Indeterminate & $196 \mathrm{~g}$ \\
\hline Roma (S.E.S.) & $\mathrm{OP}$ & 75 & Widely Adapted & $\mathrm{Bs}, \mathrm{Fw} 1, \mathrm{Vw}_{\mathrm{w}}$ & Determinate & $112 \mathrm{~g}$ \\
\hline Super Sioux (V) & $\mathrm{OP}$ & 70 & Yes & $\mathrm{Vw}$ & Indeterminate & $140 \mathrm{~g}$ \\
\hline Traveler $76(\mathrm{~V})$ & $\mathrm{OP}$ & 76 & Yes & Fw1, Vw cr, drought tolerance & Indeterminate & $224 \mathrm{~g}$ \\
\hline Tropic (S.E.S.) & $\mathrm{OP}$ & 80 & Yes & $\begin{array}{l}\text { Asc, Clm, Eb, Fw1, Gls, Rkn, Tmv1, } \\
\text { Tmv4,Vw; cr, gw, sun }\end{array}$ & Indeterminate & $227 \mathrm{~g}$ \\
\hline
\end{tabular}

${ }^{1}$ Source: Southern Exposure Seeds (S.E.S.), Victory Seeds (V), Tomato Growers Supply (T.G.S.)

${ }^{2} \mathrm{OP}=$ open pollinated; $\mathrm{F} 1$ = hybrid

${ }^{3}$ Disease abbreviations (From S.E.S catalog): Asc $=$ Alternaria stem canker, An= Anthracnose, $\mathrm{Bs}=$ bacterial spot, $\mathrm{Bw}=\mathrm{bacterial}$ wilt, $\mathrm{Clm}=\mathrm{Cladosporium}$, $\mathrm{Eb}=$ early blight (Alternaria), $\mathrm{Fw}_{\mathrm{w}} 1$ = Fusarium wilt race 1, Fw2 = Fusarium wilt race 2, Gls = gray leaf spot, Lb = late blight, Rkn = root knot nematode, Tmv = tobacco mosaic virus, $\mathrm{Tswv}=$ tomato spotted wilt virus, $\mathrm{VW}_{\mathrm{w}}=$ Verticillium wilt.

${ }^{4}$ Fruit disorders (From S.E.S catalog): ber $=$ blossom end rot, ef = catfacing, $\mathrm{cr}=$ crack resistance, gw $=$ gray wall, sun $=$ sun scald 
to Fusarium wilt, 5) heat tolerance, and 6) resistance to fruit cracking and blemishes.

The experiment was established using a randomized complete block design with four replications. Each replication was a raised bed that measured $1.8 \mathrm{~m}$ wide by $61 \mathrm{~m}$ long. Experimental units were comprised of seven plants at an in-row spacing of $0.6 \mathrm{~m}$. An extra plant was placed at the ends of each row as a border. All plots were drip irrigated using reusable $1.3 \mathrm{~cm}$ polyethylene tubing, with individual 3.7 liter per hour emitters.

To enhance biological control of insects a farmscape was planted on both sides of the variety trial (Dufour, 2000). Sunn hemp (Crotalaria juncea L.) and jack bean (Canavalia ensiformis L.) were planted in the farmscape beds to provide pollen and nectar sources as well as shelter required by beneficial insects. Sunnhemp has also been known to act as a catch crop for white flies (Pantoja et al., 1999).

Tomato seeds were sown in plastic trays with 50 cells $5 \mathrm{~cm}$ deep and $4 \mathrm{~cm}$ in diameter on 8 January 2010 for the first experiment and on 10 December 2010 for the 2011 planting. The growing medium consisted of 1 part sphagnum moss, 1 part perlite, and 1 part composted cow manure. Seedlings were later transplanted into deeper 38 cell trays and weak seedlings were culled. Seedlings were fertilized with Neptune's Harvest fish/seaweed emulsion (2-3-1) (Neptune's Harvest Fertilizer, Gloucester, Massachusetts) ${ }^{7}$ twice a week with a concentration of $10 \mathrm{ml}$ per liter, and were top dressed with $1.5 \mathrm{ml}$ of BioFlora granular fertilizer (6-6-5) (BioFlora, Goodyear, Arizona).

Composted cow manure was spread on the raised beds at a rate of 44 $\mathrm{Mg} / \mathrm{ha}$ the first season. During the second season, $22 \mathrm{Mg} / \mathrm{ha}$ of composted cow manure was mixed with $22 \mathrm{Mg} / \mathrm{ha}$ of leaf/grass compost from the University of Puerto Rico Mayagüez Campus, due to insufficient availability of composted cow manure. Typical rates for dairy manure applications are 22 to $67 \mathrm{Mg} / \mathrm{ha}$ (Sullivan, 2004). At these rates the crop would receive approximately 56 to $168 \mathrm{~kg} \mathrm{~N} / \mathrm{ha}$. This is dependent on the age and quality of the manure. Sunn hemp (Crotalaria juncea L.) was planted as a green manure cover crop the first season. Because of the lack of sunn hemp seed, cowpea (Vigna unguiculata) was used the second season. When the first flowers emerged, the plants were incorporated into the soil, which occurred approximately two months after sowing.

${ }^{7}$ Company or trade names in this publication are used only to provide specific information. Mention of a company or trade name does not constitute a warranty of equipment or materials by the Agricultural Experiment Station of the University of Puerto Rico, nor is this mention a statement of preference over other equipment or materials. 
The field trials were planted in the dry season on 10 February 2010 the first season and 26-27 January 2011 the second season. At transplanting, roots were inoculated with $5 \mathrm{ml}$ of BioVam mycorrhizal root enhancer. Arbuscular mycorrhizal (AM) fungi from BioVam inoculum can help in the absorption of slowly diffusing ions such as phosphorous and zinc (Jacobsen et al., 1992), which were at very low levels at the experimental site. BioFlora organic granular fertilizer (6-6-5) was banded around each plant ( $200 \mathrm{~g} / \mathrm{plant})$, which provided $56 \mathrm{~kg}$ of nitrogen per hectare.

To stabilize plants and stimulate the formation of adventitious roots, as well as to smother weeds prior to mulching, the plants were mounded 14 to 21 days after transplanting (DAT) by shoveling soil toward the stem. Lower leaves were removed from plants before mounding. The tomato plants were supported with one stake per plant after mounding. Two meter lengths of $1.3 \mathrm{~cm}$ diameter rebar with $1.5 \mathrm{~m}$ exposed were used for determinate tomato plants. Three-meter lengths of $1.3 \mathrm{~cm}$ diameter rebar with $2.4 \mathrm{~m}$ exposed supported indeterminate vines. Suckers were removed when they were 5 to $10 \mathrm{~cm}$ long using the thumb and the index finger. Indeterminate tomato plants are pruned more heavily than determinate plants. Indeterminate plants were pruned to approximately four to five stem leaders, depending on the amount of foliage. Determinate plants were pruned by removing lower branches, which are prone to bending and cracking under fruit load. The lower leaves and suckers were removed from both indeterminate and determinate plants to facilitate mounding and to keep leaves from direct contact with mulch, which could promote leaf fungal diseases.

Field cut grass from the experiment station was applied to the beds after mounding and staking. The mulch was applied to a depth of 20 $\mathrm{cm}$. Mulch was used to control weeds, conserve soil moisture, maintain soil tilth, lower soil temperature and prevent disease transmission (Diver et al., 1999).

In 2010 and 2011, a bi-weekly preventative spray program was used to control disease and insect pests (Tables 2 and 3). Once disease or insects become established, control becomes more difficult. All products were OMRI (Organic Materials Research Institute) approved. Foliar applications were applied with a backpack sprayer to the upper and lower surfaces of leaves. Sprays were applied at or around dawn when wind was calm, leaf stomata were open, and there was little beneficial insect activity. Visual field observations were performed on the incidence of insects and diseases throughout the entire season. Plants with virus symptoms were uprooted and eliminated from the field to reduce disease transmission. Roguing of plants with virus symptoms was discontinued after the first harvest. 
TABLE 2.-Spray schedule with OMRI (Organic Materials Review Institute) approved products during the 2010 organic tomato variety trial at the Lajas Agricultural Experiment Station.

\begin{tabular}{|c|c|}
\hline $\mathrm{DAT}^{1}$ & Product Applied \\
\hline 2 & Agree (Bt) $1 \%$ for armyworms/cutworms \\
\hline 6 & Agree $1 \%$ \\
\hline 8 & Trilogy $1 \%$ (neem oil) insecticide/ fungicide/ bactericide \\
\hline 9 & Agree $1 \%$ \\
\hline 12 & Garlic Barrier 5\% insecticide/ fungicide \\
\hline 14 & Biolink liquid fertilizer $2 \%(1-5-5)$ \\
\hline 16 & Ecotrol $0.5 \%$ (rosemary oil) for whiteflies \\
\hline 19 & Biolink liquid micronutrient fertilizer $(2 \%-\mathrm{Fe}, 2 \%-\mathrm{Mn}, 3 \%-\mathrm{Zn})$ \\
\hline 22 & Trilogy $1 \%$ \\
\hline 29 & Biolink liquid fertilizer $2 \%(1-5-5)$ \\
\hline 33 & Trilogy $1 \%$ \\
\hline 36 & Dipel (Bt) $1 \%$ \\
\hline 44 & Biolink liquid fertilizer $2 \%(1-5-5)$ \\
\hline 48 & Biolink liquid micronutrient fertilizer ( $2 \%-\mathrm{Fe}, 2 \%-\mathrm{Mn}, 3 \%-\mathrm{Zn})$ \\
\hline 49 & Ecotrol $2 \%$ \\
\hline 56 & Dipel $1 \%+$ Trilogy $1 \%$ \\
\hline 62 & Dipel $1 \%+$ Trilogy $1 \%$ \\
\hline 65 & Dipel $2 \%+$ Trilogy $2 \%$ \\
\hline 70 & $\begin{array}{l}\text { Aza-Direct } 1 \% \text { (Azadirachtin-active ingredient in neem seed kernels) for } \\
\text { white flies }\end{array}$ \\
\hline 76 & Agree $1 \%+$ Aza-Direct $1 \%$ \\
\hline 83 & Biolink liquid fertilizer $2 \%(1-5-5)$ \\
\hline 85 & Alaskan fish emulsion $1 \%$ \\
\hline 92 & Alaskan fish emulsion $1 \%+$ Trilogy $1 \%$ \\
\hline
\end{tabular}

${ }^{1} \mathrm{DAT}=$ days after transplanting to the field.

Tomato foliage was sprayed approximately five times per season with liquid organic fertilizers (Tables 2 and 3). Foliar fertilizer applications began at fruit set and continued every two to three weeks throughout the growth cycle of the tomato planting. Several products were used, depending on product availability.

Tomatoes were harvested at the color break stage of development. In the field, tomatoes were weighed and the number of fruits per plot recorded. Fruits were separated as either marketable or unmarketable (culls). Marketable fruits had no defects or gross blemishes and were considered acceptable for sale at the local organic market. Marketable fruits were not graded. Culled fruits were considered of no value either commercially or for home use. In 2010 , plots were harvested nine times: on April 15, 20,22, 27, and 30, and on May 10, 14, and 20. In 2011, tomatoes were harvested seven times: on April 7, 12, 19, 25, and 29, and on May 3 and 9. 
TABLE 3.-Spray Schedule with OMRI (Organic Materials Review Institute) approved products during the 2011 organic tomato variety trial at the Lajas Agricultural Experiment Station.

\begin{tabular}{|c|c|}
\hline DAT $^{1}$ & Product Applied \\
\hline 1 & Dipel (Bt) $1 \%$ for caterpillars + Trilogy $1 \%$ for fungicide/insecticide \\
\hline 4 & Milstop $1 \%$ for fungicide \\
\hline 8 & Trilogy $1 \%$ + Dipel $1 \%$ \\
\hline 11 & Oxidate $1 \%$ for fungicide + Trilogy $2 \%$ \\
\hline 15 & Oxidate $1 \%+$ Trilogy $2 \%$ \\
\hline 18 & Bioflora liquid fertilizer (2-1-1) $4 \%+$ Trilogy $2 \%$ \\
\hline 22 & Oxidate $1 \%+$ Trilogy $1 \%$ \\
\hline 25 & $\begin{array}{l}\text { Bioflora liquid fertilizer (2-1-1) } 6 \%+\text { Sporan EC (rosemary oil) } 1 \% \text { knock- } \\
\text { down insecticide especially for white flies }\end{array}$ \\
\hline 29 & Garlic Barrier 3\% for fungicide/insecticide + Trilogy $2 \%$ \\
\hline 32 & Oxidate $1 \%+$ Sporan EC $1 \%+$ Trilogy $1 \%$ \\
\hline 36 & Trilogy $0.75 \%+$ Sporan EC $0.75 \%+$ Garlic $0.4 \%,+$ Milstop $1 \%$ \\
\hline 39 & Trilogy $0.75 \%+$ Sporan EC $0.75 \%,+$ Garlic $0.5 \%+$ Milstop $1 \%$ \\
\hline 41 & Bioflora liquid fertilizer (2-1-1) $4 \%+\operatorname{Dipel} 1 \%$ \\
\hline 43 & Bioflora liquid ferilizer (2-1-1) $4 \%+$ Dipel $2 \%$ \\
\hline 48 & $\begin{array}{l}\text { Trilogy } 1 \%,+ \text { Sporan EC } 0.75 \%,+ \text { Dipel } 2 \%,+ \text { NuFilm } 0.25 \% \\
\text { (sticker/spreader) }\end{array}$ \\
\hline 52 & Dipel $1 \%+$ Milstop $1 \%+$ Trilogy $1 \%+$ NuFilm $0.25 \%$ \\
\hline 56 & Dipel $1 \%+$ Sporan EC $1 \%+$ Trilogy $1 \%+$ NuFilm $0.25 \%$ \\
\hline 63 & Dipel $1 \%+$ Aza-Direct $1 \%+$ Oxidate $1 \%$ \\
\hline 76 & Dipel $1 \%$ \\
\hline 82 & Bioflora liquid fertilizer (2-1-1) $2 \%$ + Garlic Barrier $2 \%+$ Sporan EC $1 \%$ \\
\hline 91 & Garlic Barrier $2 \%+$ Sporan EC $1 \%+$ oxidate $1 \%+$ NuFilm $0.25 \%$ \\
\hline
\end{tabular}

${ }^{1} \mathrm{DAT}=$ days after transplanting to the field.

As part of our organic management plan, all plants exhibiting any virus symptoms before the first harvest were eliminated to avoid total crop failure resulting from virus dissemination to healthy plants. Marketable yield in tons per hectare reflects the plants remaining per plot after roguing infected plants. Marketable yield was calculated with the following formula: Marketable yield $=$ the average marketable fruit weight/plant $\times 10,759$ plants per hectare $\times$ percentage of plants per plot at harvest/100. Yield data were analyzed for statistical significance using the Statistix 8.0 analytical software (Tallahassee, Florida).

Tomato quality attributes were assessed by measuring brix, fruit weight, fruit diameter and height, and through a consumer variety preference survey. Brix values or total soluble solids (TSS) were measured during the first or second harvest date each season with an Atago hand held refractometer model number 238342 (Tokyo, Japan). Brix values measured in this experiment were not tested for statistical significance due to small sample size $(n=5)$ each season. 
Cultivar fruit weight was calculated using the average marketable fruit weight per plant, divided by the average number of marketable fruits. Fruit diameter and fruit length measurements of five representative fruits per cultivar were measured with a hand caliper each season, at the first or second harvest date each season. Fruit diameter and fruit length measurements were not tested for statistical significance due to small sample size $(n=5)$.

A consumer variety preference survey was undertaken on three separate occasions during the harvest for both years. Tomato samples and a ripe fruit display were presented to interested adults $(n=23)$ recruited in Rincon by $\mathrm{K}$. Brady. Fully ripe and representative fruits were displayed on paper plates, which were filled to capacity. Each plate had a number code, which corresponded to a particular variety. Bite sized tomato pieces were made available in front of each cultivar's display. Evaluation forms were distributed to all the participants, who scored fruit taste and overall appearance for each cultivar. For the fruit quality evaluation, a scale of 1 to 5 was used, where $5=$ like very much, 4 = like, 3 = average, $2=$ dislike, and $1=$ dislike very much.

\section{RESULTS}

\section{Weight of marketable fruit per plant}

In 2010 , significant differences $(P<0.05)$ were found among cultivars for weight of marketable fruit per plant (Table 4). 'Roma' (6.6 kg), 'Neptune' (6.1 kg), 'BHN 444' (5.3 kg), and 'Early Girl' (4.3 kg) were among the cultivars with the greatest marketable fruit weight per plant. The average marketable fruit weight per plant ranged from 6.6 $\mathrm{kg}$ for 'Roma' to $0.8 \mathrm{~kg}$ for 'Marion'. Among the cultivars with the lowest marketable fruit weight per plant were 'Marion', 'Tropic' $(1.6 \mathrm{~kg})$, 'Super Sioux' (2.2 kg), 'Ace 55' (2.4 kg) and 'Eva Purple Ball' (2.6 kg).

In 2011 , significant differences $(\mathrm{P}<0.05)$ were also found among cultivars for marketable fruit weight per plant (Table 5). 'Early Girl' (5.1 kg), 'Flora Dade' (5.0 kg), 'BHN 444' (4.7 kg), 'Roma' (4.5 kg), 'Eva Purple Ball' (4.5 kg) 'Traveler 76' (4.3 kg), and 'Celebrity' (3.9 kg) were among the cultivars with the highest marketable fruit weight per plant. The average marketable fruit weight per plant ranged from 5.1 $\mathrm{kg}$ for 'Early Girl' to $2.2 \mathrm{~kg}$ for 'Super Sioux'. Among the cultivars with the lowest marketable fruit weight per plant were 'Super Sioux', 'Ace 55 ' $(2.6 \mathrm{~kg})$, and 'Marion' $(2.6 \mathrm{~kg})$,

Marketable fruit weight per plant was significantly different $(\mathrm{P}<$ 0.5 ) from year to year as was the cultivar by year interaction. The average marketable fruit weight per plant was higher in $2011(3.9 \mathrm{~kg})$ than 
TABLE 4.-Total fruit weight/plant, weight of marketable fruit/plant, percentage of culls, number of marketable fruits/plant, and total number of fruits/plant of tomato cultivars grown under organic management, 2010-winter/spring season, Agricultural Experiment Station, Lajas, Puerto Rico.

\begin{tabular}{lccccc}
\hline Cultivar & $\begin{array}{c}\text { Total fruit wt./plant } \\
(\mathrm{kg})\end{array}$ & $\begin{array}{c}\text { Weight of marketable } \\
\text { fruit/plant }(\mathrm{kg})\end{array}$ & $\begin{array}{c}\text { \% Culls } \\
\text { (by weight) }\end{array}$ & $\begin{array}{c}\text { Number of marketable } \\
\text { fruits/plant }\end{array}$ & $\begin{array}{c}\text { Total number } \\
\text { of fruits/plant }\end{array}$ \\
\hline Ace 55 & $5.0 \mathrm{de}$ & $2.4 \mathrm{ghi}$ & $52 \mathrm{bc}$ & $12 \mathrm{ef}$ & $27 \mathrm{~g}$ \\
BHN 444 & $7.7 \mathrm{a}$ & $5.3 \mathrm{bc}$ & $31 \mathrm{~d}$ & $24 \mathrm{c}$ & $38 \mathrm{~cd}$ \\
Celebrity & $6.8 \mathrm{abc}$ & $3.9 \mathrm{de}$ & $45 \mathrm{c}$ & $20 \mathrm{~cd}$ & $41 \mathrm{c}$ \\
Early Girl & $5.9 \mathrm{bcd}$ & $4.3 \mathrm{~cd}$ & $29 \mathrm{def}$ & $37 \mathrm{~b}$ & $57 \mathrm{~b}$ \\
Eva Purple Ball & $3.6 \mathrm{f}$ & $2.6 \mathrm{fghi}$ & $27 \mathrm{def}$ & $19 \mathrm{cde}$ & $28 \mathrm{fg}$ \\
Flora Dade & $6.6 \mathrm{abc}$ & $3.7 \mathrm{def}$ & $44 \mathrm{c}$ & $25 \mathrm{c}$ & $51 \mathrm{~b}$ \\
Homestead 24 & $6.4 \mathrm{abcd}$ & $3.5 \mathrm{defg}$ & $46 \mathrm{c}$ & $17 \mathrm{cde}$ & $35 \mathrm{cdef}$ \\
Marion & $2.7 \mathrm{f}$ & $0.8 \mathrm{j}$ & $73 \mathrm{a}$ & $9 \mathrm{f}$ & $25 \mathrm{~g}$ \\
Neptune & $7.3 \mathrm{ab}$ & $6.1 \mathrm{ab}$ & $17 \mathrm{fg}$ & $52 \mathrm{~b}$ \\
Ozark Pink & $4.1 \mathrm{ef}$ & $3.3 \mathrm{defgh}$ & $18 \mathrm{fg}$ & $9 \mathrm{c}$ & $122 \mathrm{a}$ \\
Roma & $7.3 \mathrm{ab}$ & $6.6 \mathrm{a}$ & $59 \mathrm{~b}$ & $14 \mathrm{def}$ & $138 \mathrm{efg}$ \\
Super Sioux & $5.4 \mathrm{~cd}$ & $2.2 \mathrm{hi}$ & $19 \mathrm{efg}$ & $23 \mathrm{c}$ & $36 \mathrm{cde}$ \\
Traveler 76 & $3.6 \mathrm{f}$ & $3.0 \mathrm{efgh}$ & $61 \mathrm{~b}$ & $9 \mathrm{f}$ & $32 \mathrm{defg}$ \\
Tropic & $4.1 \mathrm{ef}$ & $1.6 \mathrm{ij}$ & 38 & 28 & $25 \mathrm{~g}$ \\
Average & 5.5 & 3.5 & & 44
\end{tabular}

${ }^{1}$ In a column, means followed by the same letter are not significantly different at $\mathrm{P}=0.05$ level by Fisher's LSD Test. 
TABLE 5.-Marketable fruit weight/plant, total fruit weight/plant, percentage of culls, number of marketable fruits / plant, and total number of fruits/plant of tomato cultivars grown under organic management, 2011-winter/spring season, Agricultural Experiment Station, Lajas, Puerto Rico.

\begin{tabular}{|c|c|c|c|c|c|}
\hline Cultivar & $\begin{array}{l}\text { Total fruit wt./plant } \\
(\mathrm{kg})\end{array}$ & $\begin{array}{c}\text { Weight of marketable } \\
\text { fruit/plant }(\mathrm{kg})\end{array}$ & $\begin{array}{c}\% \text { Culls } \\
\text { (by weight) }\end{array}$ & $\begin{array}{c}\text { Number of marketable } \\
\text { fruits/plant }\end{array}$ & $\begin{array}{l}\text { Total number } \\
\text { of fruits/plant }\end{array}$ \\
\hline Ace 55 & $5.0 c^{1}$ & $2.6 \mathrm{de}$ & $51 \mathrm{ab}$ & $11 \mathrm{~d}$ & $24 \mathrm{c}$ \\
\hline $\mathrm{BHN} 444$ & $6.8 \mathrm{ab}$ & $4.7 \mathrm{a}$ & $30 \mathrm{~cd}$ & 22 bcd & $32 \mathrm{bc}$ \\
\hline Celebrity & $7.3 \mathrm{a}$ & $4.3 \mathrm{abc}$ & $42 \mathrm{bc}$ & $21 \mathrm{~cd}$ & $37 \mathrm{bc}$ \\
\hline Early Girl & $7.3 \mathrm{a}$ & $5.1 \mathrm{a}$ & $30 \mathrm{~cd}$ & $40 \mathrm{~b}$ & $67 \mathrm{~b}$ \\
\hline Eva Purple Ball & $5.4 \mathrm{bc}$ & $4.5 \mathrm{ab}$ & $20 \mathrm{~d}$ & $25 \mathrm{bcd}$ & $41 \mathrm{bc}$ \\
\hline Flora Dade & $7.3 \mathrm{a}$ & $5.0 \mathrm{a}$ & $30 \mathrm{~cd}$ & $28 \mathrm{bcd}$ & $47 \mathrm{bc}$ \\
\hline Homestead 24 & $5.9 \mathrm{abc}$ & $3.8 \mathrm{bc}$ & $27 \mathrm{~d}$ & $17 \mathrm{~cd}$ & $27 \mathrm{c}$ \\
\hline Marion & $5.9 \mathrm{abc}$ & $2.6 \mathrm{de}$ & $57 \mathrm{a}$ & $16 \mathrm{~cd}$ & $39 \mathrm{bc}$ \\
\hline Neptune & $5.0 \mathrm{c}$ & $3.5 \mathrm{~cd}$ & $27 \mathrm{~d}$ & $30 \mathrm{bc}$ & $32 \mathrm{bc}$ \\
\hline Ozark Pink & $5.0 \mathrm{c}$ & $3.8 \mathrm{bc}$ & $20 \mathrm{~d}$ & $23 \mathrm{bcd}$ & $32 \mathrm{bc}$ \\
\hline Roma & $5.4 \mathrm{bc}$ & $4.5 \mathrm{ab}$ & $5 \mathrm{e}$ & $75 \mathrm{a}$ & $96 \mathrm{a}$ \\
\hline Super Sioux & $5.0 \mathrm{c}$ & $2.2 \mathrm{e}$ & $56 \mathrm{a}$ & $14 \mathrm{~cd}$ & $37 \mathrm{bc}$ \\
\hline Traveler 76 & $5.4 \mathrm{bc}$ & $4.3 \mathrm{abc}$ & $22 \mathrm{~d}$ & $26 \mathrm{bcd}$ & $35 \mathrm{bc}$ \\
\hline Tropic & $6.6 \mathrm{abc}$ & $3.5 \mathrm{~cd}$ & $46 \mathrm{ab}$ & $15 \mathrm{~cd}$ & $37 \mathrm{bc}$ \\
\hline Average & 6.0 & 3.9 & 33.1 & 26 & 42 \\
\hline
\end{tabular}

${ }^{1}$ In a column, means followed by the same letter are not significantly different at $\mathrm{P}=0.05$ level by Fisher's LSD test. 
in 2010 ( $3.5 \mathrm{~kg}$ ) (Tables 4 and 5). The open pollinated cultivars varied more from year to year than the hybrid controls for marketable fruit weight per plant. Open pollinated cultivars that were high yielders in 2010, like 'Roma' and 'Neptune', were not in 2011, and low performers in 2010, like 'Eva Purple Ball' and 'Traveler 76', improved in 2011 (Tables 4 and 5). On average, the top performing cultivars in the two-year trial for marketable fruit weight per plant included 'Roma' $(5.5 \mathrm{~kg})$, 'BHN 444' (5.0 kg), 'Neptune' (5.0 kg), and 'Early Girl' (4.7 kg). 'Marion' $(1.6 \mathrm{~kg})$ and 'Super Sioux' $(2.2 \mathrm{~kg})$ were among the cultivars with the lowest marketable fruit weight per plant over the two year study.

Percentage of culled (unmarketable) fruit by weight

In 2010, significant differences $(\mathrm{P}<0.05)$ were found among cultivars for the percentage of culled fruit by weight (Table 4). 'Roma' (9\%), 'Neptune' (17\%), 'Ozark Pink' (18\%), and 'Traveler 76' (19\%) were among the cultivars that produced less culled fruit as a percentage of total yield. The average percentage of culled fruit by weight ranged from $9 \%$ for 'Roma' to 73\% for 'Marion'. Among the cultivars that produced the most culled fruit by weight were 'Marion', 'Tropic' (61\%), 'Super Sioux' (59\%) and 'Ace 55 ' $(52 \%)$. In 2010 , radial fruit cracking, followed by caterpillar damage, were the most common cause of culled fruit.

In 2011, significant differences $(P<0.05)$ were also found among cultivars for the percentage of culled fruit by weight (Table 5). Among the cultivars that produced the least culled fruit as a percentage of total yield were 'Roma' (5\%) and all the pink tomatoes; 'Eva Purple Ball' $(20 \%)$, 'Ozark Pink' (20\%), and 'Traveler 76' (22\%). The average percentage of culled fruit by weight ranged from 5\% for 'Roma' to 57\% for 'Marion'. Among the cultivars that produced the most culled fruit by weight were 'Marion', 'Super Sioux' (56\%), 'Ace 55' (51\%), and 'Tropic' (46\%). In 2011, radial cracking was the most common cause of culled fruit.

The percentage of culled fruit by weight was significantly different $(\mathrm{P}<0.05)$ between years, with $38 \%$ culls in 2010 , and $33 \%$ culls in 2011. 'Homestead', 'Marion' and 'Tropic' had at least $15 \%$ more culled fruit by weight in 2010 than in 2011 (Tables 4 and 5). Over the two-year study cultivars with greater than $50 \%$ culled fruit included 'Marion' (65\%), 'Super Sioux' (57\%), 'Tropic' (54\%), and 'Ace 55' (51\%). Cultivars with a high percentage of culled fruits will have limited commercial value. Overall, the cultivars with the least amount of culled fruit included 'Roma' (7\%), 'Ozark Pink' (19\%), and 'Traveler 76' (21\%).

\section{Number of marketable fruits per plant}

In 2010, significant differences $(\mathrm{P}<0.05)$ were found among cultivars in the number of marketable fruits per plant (Table 4). The mean 
number of marketable fruits per plant ranged from 122 for 'Roma' to seven for 'Marion'. 'Roma', the only cultivar with a small plum-type fruit, produced significantly $(\mathrm{P}<0.05)$ more fruits per plant than all other cultivars. 'Marion', 'Tropic' (9), and 'Ace 55' (12) were among the lowest yielding cultivars.

In 2011, significant differences $(\mathrm{P}<0.05)$ were found among cultivars for number of marketable fruits per plant (Table 5). The total number of marketable fruits per plant ranged from 75 for 'Roma' to 11 for 'Ace 55'. 'Roma' produced significantly ( $\mathrm{P}<0.05$ ) more marketable fruits per plant than all other cultivars. 'Ace 55', 'Marion (12), 'Super Sioux' (14), and 'Tropic' (15) were among the lowest yielding cultivars.

Over the two-year study, the top two cultivars with the highest number of marketable fruits per plant were also those with the smallest fruit weight. 'Roma' (99), and 'Early Girl' (39) were among the cultivars which produced the greatest number of marketable fruits per plant. 'Marion' (11), 'Ace 55' (11), 'Tropic' (14), and 'Super Sioux' (15) were among the cultivars which had the smallest number of fruits per plant.

\section{Marketable yield}

In 2010, significant differences $(\mathrm{P}<0.05)$ were found among cultivars for marketable yield (Table 6). 'Roma'( $72.1 \mathrm{Mg} / \mathrm{ha}$ ), 'Neptune'(56.8 $\mathrm{Mg} / \mathrm{ha}$ ), and 'BHN 444 ' (56.2 Mg/ha), were among the cultivars which had the greatest marketable yields. The marketable yield ranged from $72.1 \mathrm{Mg} / \mathrm{ha}$ for 'Roma' to $8.6 \mathrm{Mg} / \mathrm{ha}$ for 'Marion'. Cultivars that were among the lowest yielders included 'Marion' and 'Tropic' (16 Mg/ha).

In 2011 , significant differences $(P<0.05)$ were found among cultivars for marketable yield (Table 7). 'Flora Dade' (46.1 Mg/ha), 'BHN 444 ' (43.5 Mg/ha), and 'Celebrity' (38.3 Mg/ha) were among the cultivars which had the greatest marketable yields. The marketable yield ranged from $46.1 \mathrm{Mg} / \mathrm{ha}$ for 'Flora Dade' to $8.7 \mathrm{Mg} / \mathrm{ha}$ for 'Roma'. Cultivars that were among the lowest yielders were 'Roma', 'Marion' (17.1 Mg/ha), 'Traveler 76' (21.5 Mg/ha), 'Super Sioux' (21.8 Mg/ha) and 'Ozark Pink' (22.2 Mg/ha). The poor performance of 'Roma' in 2011 was due to high incidence of virus infection, leading to $82 \%$ loss of plants because of roguing (Table 7 ).

\section{Consumer preference evaluation}

Taste and overall fruit appearance evaluations were made on all varieties by a panel of adult volunteers. In 2010 , 'Ace 55 ' (4.4) and 'Early Girl' (4.1) were among the cultivars that were judged to have better tasting fruit, followed by 'Celebrity', 'Ozark Pink', and 'Super Sioux', all of which had a score of 3.9 (Table 8). The average taste test scores 
TABLE 6.-Marketable yield $(M g / h a)$ and percentage of plants eliminated before first harvest due to virus symptoms, 2010 organic tomato variety trial, Agricultural Experiment Station, Lajas, Puerto Rico.

\begin{tabular}{lcc}
\hline Cultivar & Marketable Yield $(\mathbf{M g} / \mathrm{ha})^{1}$ & $\begin{array}{c}\text { \% Plants Rogued due to Virus } \\
\text { Symptoms }\end{array}$ \\
\hline Ace 55 & $23.3 \mathrm{gh}^{2}$ & 7 \\
BHN 444 & $56.2 \mathrm{bc}$ & 0 \\
Celebrity & $41.8 \mathrm{de}$ & 0 \\
Early Girl & $44.8 \mathrm{~cd}$ & 4 \\
Eva Purple Ball & $26.8 \mathrm{fgh}$ & 4 \\
Flora Dade & $39.9 \mathrm{def}$ & 0 \\
Homestead 24 & $38.1 \mathrm{def}$ & 0 \\
Marion & $8.6 \mathrm{i}$ & 0 \\
Neptune & $56.8 \mathrm{ab}$ & 11 \\
Ozark Pink & $33.9 \mathrm{defg}$ & 4 \\
Roma & $72.1 \mathrm{a}$ & 0 \\
Super Sioux & $23.2 \mathrm{gh}$ & 4 \\
Traveler 76 & $28.3 \mathrm{efg}$ & 11 \\
Tropic & $16.0 \mathrm{hi}$ & 7 \\
Average & 36.4 & 2.9 \\
\hline
\end{tabular}

${ }^{1}$ Marketable yield $=$ avg. fruit wt. $/$ plant $\times 10,759$ plants/ha $\times$ percentage of plants per plot at harvest $/ 100$.

${ }^{2}$ In a column, means followed by the same letter are not significantly different at $\mathrm{P}=0.05$ level by Fisher's LSD test.

ranged from 4.4 for 'Ace 55 ' to 2.8 for 'BHN 444 '. The average taste test score for 'BHN 444' was less than all other cultivars.

In 2011, 'Early Girl' (4.4) and 'Super Sioux' (4.2) were among the cultivars which received a higher taste score, followed by 'Ace 55', 'Eva Purple Ball', and 'Marion', all of which had a score of 4.0 (Table 8). The average taste test scores ranged from 4.4 for 'Early Girl' to 2.6 for 'Neptune'. The average taste test scores for 'Neptune' and 'Roma' (3.0) were among the lowest of all cultivars.

In 2010, 'Early Girl' (4.8) and 'Neptune' (4.3) were among the cultivars which were judged to have fruit of better overall appearance, followed by 'Ace 55' (4.1), 'Homestead 24' (4.1), 'BHN 444' (4.0) and 'Tropic' (4.0) (Table 8). The average overall appearance scores ranged from 4.8 for 'Early Girl' to 3.2 for 'Super Sioux'. Among the cultivars with the lowest overall appearance scores were 'Super Sioux' and 'Ozark Pink' (3.6).

In 2011, 'Early Girl' (4.7) and 'Traveler 76 ' (4.2) were among the cultivars with the highest overall appearance score, followed by 'Neptune' (4.1), 'Ozark Pink' (4.1), and 'Roma' (4.1). The average overall appearance scores ranged from 4.7 for 'Early Girl' to 3.4 for 'Flora Dade' 
TABLE 7.-Marketable yield $(M g / h a)$ and percentage of plants eliminated before first harvest due to virus symptoms, 2011 organic tomato variety trial, Agricultural Experiment Station, Lajas, Puerto Rico.

\begin{tabular}{lcc}
\hline Cultivar & Marketable Yield $(\mathrm{Mg} / \mathrm{ha})^{1}$ & $\begin{array}{c}\text { \% Plants Rogued due to Virus } \\
\text { Symptoms }\end{array}$ \\
\hline Ace 55 & $25.8 \mathrm{c}^{2}$ & 7 \\
BHN 444 & $43.5 \mathrm{ab}$ & 15 \\
Celebrity & $38.3 \mathrm{abc}$ & 29 \\
Early Girl & $29.3 \mathrm{bc}$ & 46 \\
Eva Purple Ball & $24.2 \mathrm{~cd}$ & 50 \\
Flora Dade & $46.1 \mathrm{a}$ & 15 \\
Homestead 24 & $24.9 \mathrm{c}$ & 39 \\
Marion & $17.1 \mathrm{~cd}$ & 39 \\
Neptune & $31.3 \mathrm{bc}$ & 18 \\
Ozark Pink & $22.2 \mathrm{~cd}$ & 46 \\
Roma & $8.7 \mathrm{~d}$ & 82 \\
Super Sioux & $21.8 \mathrm{~cd}$ & 7 \\
Traveler 76 & $21.5 \mathrm{~cd}$ & 54 \\
Tropic & $34.7 \mathrm{bc}$ & 36 \\
Average & 27.8 & 34.6 \\
\hline
\end{tabular}

${ }^{1}$ Marketable yield $=$ avg. fruit wt./plant $\times 10,759$ plants $/$ ha $\times$ percentage of plants per plot at harvest 100 .

${ }^{2}$ In a column, means followed by the same letter are not significantly different at $\mathrm{P}=0.05$ level by Fisher's LSD test.

and 'Marion'. Among the cultivars with the lowest overall appearance scores were 'Flora Dade' and 'Marion', and 'Super Sioux' (3.5).

Fruit brix values

In 2010, the cultivars which were among those with the highest brix ratings were 'Early Girl (5.3), 'Eva Purple Ball' (4.8), and 'Super Sioux (4.7). The brix ratings ranged from 5.3 for 'Early Girl' to 3.4 for 'Roma' (Table 9). The average brix value for all the cultivars was 4.3, which is the same as that reported by Palada and Davis (2001) for 12 hybrid tomato cultivars grown under organic management in the U.S Virgin Islands.

In 2011, the cultivars which were among those with the highest brix ratings were 'Early Girl' (5.3), 'Ozark Pink' (4.8), and 'Tropic'(4.8). The brix ratings ranged from 5.3 for 'Early Girl' to 3.9 for 'Neptune' (Table 9). The average brix value for all the cultivars was 4.5 .

\section{Fruit weight}

In 2010, significant differences $(\mathrm{P}<0.05)$ were found among cultivars for the average weight per fruit (Table 9). 'BHN 444' (224 g) and 'Homestead 24 ' (211 $\mathrm{g}$ ) were among those cultivars which produced 
TABLE 8.-Consumer preference survey results for fruit taste and overall fruit appearance of tomato cultivars grown under organic management, 2010/ 2011 winter / spring seasons, Agricultural Experiment Station, Lajas, Puerto Rico.

\begin{tabular}{llllll}
\hline & \multicolumn{2}{c}{ Fruit taste $^{1}$} & & \multicolumn{2}{c}{ Overall fruit appearance $^{1}$} \\
\cline { 2 - 3 } \cline { 5 - 6 } Cultivar & 2010 & 2011 & & 2010 & 2011 \\
\hline Ace 55 & $4.4 \mathrm{a}^{2}$ & $4.0 \mathrm{abc}$ & & $4.1 \mathrm{bc}$ & $3.6 \mathrm{cde}$ \\
BHN 444 & $2.8 \mathrm{e}$ & $3.7 \mathrm{bcd}$ & & $4.0 \mathrm{bcd}$ & $3.9 \mathrm{bcd}$ \\
Celebrity & $3.9 \mathrm{abc}$ & $3.8 \mathrm{bc}$ & & $3.7 \mathrm{cde}$ & $3.8 \mathrm{bcde}$ \\
Early Girl & $4.1 \mathrm{ab}$ & $4.4 \mathrm{a}$ & & $4.8 \mathrm{a}$ & $4.7 \mathrm{a}$ \\
Eva Purple Ball & $3.5 \mathrm{de}$ & $4.0 \mathrm{abc}$ & & $3.8 \mathrm{~cd}$ & $4.0 \mathrm{bc}$ \\
Flora Dade & $3.5 \mathrm{de}$ & $3.2 \mathrm{de}$ & & $3.8 \mathrm{~cd}$ & $3.4 \mathrm{e}$ \\
Homestead 24 & $3.6 \mathrm{~cd}$ & $3.8 \mathrm{bc}$ & & $4.1 \mathrm{bc}$ & $3.9 \mathrm{bcd}$ \\
Marion & $3.7 \mathrm{bc}$ & $4.0 \mathrm{abc}$ & & $2.4 \mathrm{f}$ & $3.4 \mathrm{e}$ \\
Neptune & $3.5 \mathrm{de}$ & $2.6 \mathrm{f}$ & & $4.3 \mathrm{ab}$ & $4.1 \mathrm{~b}$ \\
Ozark Pink & $3.9 \mathrm{abc}$ & $3.9 \mathrm{bc}$ & & $3.6 \mathrm{de}$ & $4.1 \mathrm{~b}$ \\
Roma & $3.6 \mathrm{~cd}$ & $3.0 \mathrm{ef}$ & & $3.9 \mathrm{bcd}$ & $4.1 \mathrm{~b}$ \\
Super Sioux & $3.9 \mathrm{abc}$ & $4.2 \mathrm{ab}$ & & $3.2 \mathrm{e}$ & $3.5 \mathrm{de}$ \\
Traveler 76 & $3.8 \mathrm{bc}$ & $3.7 \mathrm{bcd}$ & & $3.7 \mathrm{cde}$ & $4.2 \mathrm{ab}$ \\
Tropic & $3.8 \mathrm{bc}$ & $3.9 \mathrm{bc}$ & & $4.0 \mathrm{bcd}$ & $4.0 \mathrm{bc}$ \\
Average & 3.7 & 3.7 & & 3.8 & 3.9 \\
\hline
\end{tabular}

${ }^{1}$ Rating scale; $5=$ like very much, $4=$ like, $3=$ average, $2=$ dislike, $1=$ dislike very much.

${ }^{2}$ In a column, means followed by the same letter are not significantly different at $P=0.05$ level by Fisher's LSD test.

fruit of greater weight, followed by 'Ace 55' (198 g) and 'Celebrity' (194 $\mathrm{g}$ ). The average weight per fruit ranged from $224 \mathrm{~g}$ for ' $\mathrm{BHN} 444$ ' to 55 $\mathrm{g}$ for 'Roma'. 'Marion' (112 g) and 'Early Girl' (117 g) were among the cultivars which produced fruit of less weight.

In 2011, significant differences $(\mathrm{P}<0.05)$ were also found among cultivars for the average weight per fruit (Table 9). 'Ace 55' (236 g), 'BHN 444' (224 g), and 'Homestead 24' (223 g) were among those which produced fruit of greater weight, followed by 'Celebrity' $(205 \mathrm{~g})$ and 'Tropic' (184 g). The average weight per fruit ranged from $236 \mathrm{~g}$ for 'Ace 55' to $60 \mathrm{~g}$ for 'Roma'. 'Roma' and 'Early Girl' (116 g) were among those which produced fruit of less weight. They were also among the top yielders for marketable fruit per plant.

There was no significant interaction for cultivar fruit weight between years. Overall, 'BHN 444' (224 g) and 'Ace 55' (217 g) were among the cultivars which produced fruit of greater weight. 'Roma' (58 g) and 'Early Girl' (117 g) were among those which produced fruit of less weight. The average fruit weight for all the cultivars was less in 2010 (157 g) than in 2011 ( $165 \mathrm{~g})$. In 2010 , there was a greater average number of marketable fruits per plant than in 2011, which may have contributed to lower individual fruit weight in 2010 . 
TABLE 9.-Brix (total soluble solids) and individual fruit weight of tomato cultivars grown under organic management, 2010/2011-winter/spring seasons, Agricultural Experiment Station, Lajas, Puerto Rico.

\begin{tabular}{lccccc}
\hline & \multicolumn{3}{c}{ Brix $^{1}$} & & \multicolumn{2}{c}{ Fruit Weight (g) } \\
\cline { 2 - 3 } \cline { 5 - 6 } Cultivar & 2010 & 2011 & & 2010 & 2011 \\
\hline Ace 55 & 4.6 & 4.7 & & $198 \mathrm{abc}^{2}$ & $236 \mathrm{a}$ \\
BHN 444 & 3.6 & 4.5 & & $224 \mathrm{a}$ & $224 \mathrm{ab}$ \\
Celebrity & 4.4 & 4.2 & & $194 \mathrm{bc}$ & $205 \mathrm{abc}$ \\
Early Girl & 5.3 & 5.3 & & $117 \mathrm{gh}$ & $116 \mathrm{e}$ \\
Eva Purple Ball & 4.8 & 4.7 & & $141 \mathrm{efg}$ & $141 \mathrm{de}$ \\
Flora Dade & 3.7 & 4.0 & & $150 \mathrm{ef}$ & $161 \mathrm{cde}$ \\
Homestead 24 & 4.6 & 4.1 & & $211 \mathrm{ab}$ & $223 \mathrm{ab}$ \\
Marion & 4.5 & 4.6 & & $112 \mathrm{~h}$ & $163 \mathrm{cde}$ \\
Neptune & 4.3 & 3.9 & & $151 \mathrm{ef}$ & $117 \mathrm{e}$ \\
Ozark Pink & 4.4 & 4.8 & & $162 \mathrm{de}$ & $165 \mathrm{cde}$ \\
Roma & 3.4 & 4.7 & & $55 \mathrm{i}$ & $60 \mathrm{f}$ \\
Super Sioux & 4.7 & 4.7 & & $159 \mathrm{def}$ & $157 \mathrm{de}$ \\
Traveler 76 & 3.8 & 4.6 & & $133 \mathrm{fgh}$ & $165 \mathrm{cde}$ \\
Tropic & 4.4 & 4.8 & & $185 \mathrm{~cd}$ & $184 \mathrm{bcd}$ \\
Average & 4.3 & 4.5 & & 157 & 166 \\
\hline
\end{tabular}

${ }^{1}$ Statistical analyses were not conducted due to small sample size ( $\mathrm{n}=5$ fruits per cultivar).

${ }^{2}$ In a column, means followed by the same letters are not significantly different at $P=0.05$ level by Fisher's LSD test.

\section{DISCUSSION}

Tomato fruit cracking can significantly affect yield and quality performance. In the 2010 and 2011 organic variety trials at Lajas, fruit cracking was a major problem for some cultivars. The overall percentage of cracked fruit was 38\% in 2010 and 33\% in 2011. Though high, these figures are comparable to Palada and Davis (2001) organic variety trial in the U.S. Virgin Islands. In 1999, they had $29 \%$ culled fruit and $36 \%$ in 2000.

Fruit cracking can be reduced through cultivar resistance (Jones, 1999) and management strategies. Cultivar crack resistance might be due to morphological adaptations, like an elastic cuticle layer (Cheryld et al., 1997), which indicates that fruit cracking may be under genetic influence. Peet and Willitis (1995) reported that extremes in water supply, high light intensity and high temperatures could cause fruit cracking. To help reduce fruit cracking, especially when heavy rains are predicted, fruit can be harvested less ripe. Harvesting tomatoes in the cool/dry months of winter, along with controlled irrigation practices, may help to reduce the incidence of fruit cracking. In this experiment, tomato plants were trained to a single stake with heavy sucker 
removal and leaf pruning. This practice could expose the tomatoes to higher temperatures and accelerate fruit cracking. Caging tomatoes could be an alternative to staking. Caged tomatoes have a higher ratio of foliage to fruit because they require little pruning, and more foliage can shield fruit from excessive heat.

Yields of field-grown tomatoes usually range between 40 to $100 \mathrm{Mg}$ / ha in Europe and North America (Heuvelink and Doris, 2005), mostly under conventionally managed systems with hybrid varieties. Kaffka et al. (2005) reported average marketable fruit yields of $63 \mathrm{Mg} /$ ha for organically grown hybrid processing tomatoes in California. Juroszek et al. (2008) conducted a replicated trial at three different organic farms in Taiwan, using two hybrid processing tomato varieties. The marketable fruit yields were $22.2 \mathrm{Mg} / \mathrm{ha}$ in Sihun, $34.7 \mathrm{Mg} / \mathrm{ha}$ in Madou, and $55.1 \mathrm{Mg} / \mathrm{ha}$ in Shinhua. Higher yields in Shinhua were related to higher soil fertility, appropriate climate conditions, timely management skills, and the availability of Bacillus thuringiensis $(\mathrm{Bt})$ for insect control.

In 1999 and 2000, Palada and Davis (2001) conducted a replicated organic tomato variety trial with 12 slicing type hybrids in the U.S Virgin Islands. They demonstrated that tomatoes could be successfully grown under organic management in the tropics and achieved yields comparable to the conventional sector. In the organic variety trial at Lajas, Puerto Rico, average marketable yield of 11 open pollinated cultivars and three hybrids was $36.4 \mathrm{Mg} / \mathrm{ha}$ in 2010 and $27.8 \mathrm{Mg} / \mathrm{ha}$ in 2011 (Tables 6 and 7). In comparison, average marketable yield of 12 hybrid varieties in the U.S Virgin Islands was $37 \mathrm{Mg} / \mathrm{ha}$ in 1999 and $27 \mathrm{Mg} / \mathrm{ha}$ in 2000 .

In the 2010 and 2011 organic variety trials in Lajas, the open pollinated cultivars produced the highest yields both years, but their individual performance varied more than the hybrid controls. In 2010, the open pollinated cultivars 'Roma' (72 Mg/ha) and 'Neptune' (57 Mg/ha) were among those which produced the highest marketable yields (Table 6). The three hybrid controls, 'BHN $444^{\prime}(56 \mathrm{Mg} / \mathrm{ha}$ ), 'Early Girl' ( $45 \mathrm{Mg}$ / ha), and 'Celebrity' ( $42 \mathrm{Mg} / \mathrm{ha}$ ) followed closely behind the leaders. In 2011, the open pollinated cultivar 'Flora Dade' ( $46 \mathrm{Mg} / \mathrm{ha}$ ) was among the cultivars which produced the highest marketable yield. The two hybrids 'BHN 444' (44 Mg/ha), and 'Celebrity' (38 Mg/ha) also had high marketable yields (Table 7). The three hybrid control cultivars ranked in the top six for marketable yield in both 2010 and 2011. Due to their heterozygous nature, hybrids can be expected to achieve greater yield stability through time and space than homozygous open pollinated cultivars (Allard and Bradshaw, 1964). Hybrids are genetically more diverse than open pollinated cultivars, which allows for greater adap- 
tion to changing climatic conditions. Yet, hybrids cannot be selectively bred by farmers and adapted to local conditions, which limits their use in sustainable organic agriculture. To achieve yield stability with open pollinated cultivars, farmers can plant a genetically diverse mix of locally adapted open pollinated cultivars. With greater genetic diversity, the farmer has greater insurance that at least some cultivars will have an adaptive advantage under shifting environmental conditions.

\section{CONCLUSIONS}

This experiment has shown that tomato can be successfully grown under an organic management system in Lajas, Puerto Rico, during the dry season. In both 2010 and 2011, there were significant differences in yield and quality performance among cultivars. The hybrid control 'Early Girl' was one of the most promising cultivars in the two-year study in terms of taste, yield, and overall fruit appearance. 'Early Girl' appears to be well adapted to the organic farm-system in Lajas, Puerto Rico, and is recommended to organic growers. The open-pollinated tomato cultivars varied more in performance than the hybrid controls. The open pollinated cultivars which ranked highest in the combined two year study in terms of taste, yield, and overall fruit appearance were 'Roma', 'Homestead 24', 'Ozark Pink', and 'Traveler 76'. To attain yield stability with these or other open pollinated tomato cultivars, farmers can consider planting a genetically diverse mix of cultivars at each planting. This strategy could help increase the adaptive capacity and overall performance of the tomato farm system as environmental conditions change. Furthermore, a cultivar mix may help to spread out the harvest period and diverse fruit types may appeal to consumers.

This trial screened only a small percentage of the open pollinated varieties available. There is a need to test more suitable cultivars under organic management, so we can access the best regionally adapted cultivars available on the market. Potential researchers may consider having an observational organic variety trial before a replicated trial. Observational trials can screen large numbers of cultivars in one experiment. This screening could greatly improve the efficiency of the replicated trial by eliminating the lowest performing cultivars. Also, an observational trial can help refine the organic management plan before the replicated trial.

\section{LITERATURE CITED}

Allard, R. and A. Bradshaw, 1964. Implications of genotype-environment interactions in applied plant breeding. Crop Science 4: 503-508.

Almodóvar, A. and C. I. Álamo, 1999. Trends in the production and export of winter tomato in Puerto Rico and the United States before and after NAFTA during 1990- 
1997. Proceedings of the 35th Annual Meeting, Caribbean Food Crops Society, Castries, St. Lucia, 25-31 July. p. 31-38.

Cheryld, L., W. Emmons and W. Scott, 1997. Environmental and physiological effects on cuticle cracking in tomato. J. Am. Soc. Hort. Sci. 122: 797-801.

Colberg-Rivera, O., R. Vélez-Colón, C. Álamo-González and C. Chao de Báez, 1996. Fresh market tomato cultivar trials at two locations. J. Agric.Univ. P.R. 80(3): 207-210

Colley, M. and J. Myers, 2007. On-farm variety trials: A guide for organic vegetable, herb, and flower producers. Organic Seed Alliance. http://www.seedalliance.org/uploads/publications/OVT_Guide.pdf (viewed 17 April 2011)

Department of Agriculture of Puerto Rico, 2010. Ingreso Bruto Agrícola año fiscal 20082009. Oficina de Estadísticas Agrícolas. p.19

Department of Agriculture of Puerto Rico, 2012. Resumen grupos alimenticios. http:/ www.pr.gov/agencias/Agricultura/estadisticas/Documents/Estadisticas/resumen consumo2010preliminar abril 2012.pdf (viewed 29 October 2013)

Diver, S., G. Kuepper and H. Born, 1999. Organic tomato production. Horticulture production guide. Appropriate Technology Transfer for Rural Areas (ATTRA). http//:www.attra.org/attra-pub/tomato.html (viewed 13 April 2009)

Dufour, R., 2000. Farmscaping to enhance biological control. Appropriate Technology Transfer for Rural Areas (ATTRA). December. http//:www.attra.ncat.org/attra-pub/ farmscape.html (viewed 13 December 2010)

Fornaris, G., R. Guadalupe, I. Beauchamp de Caloni and C. Chao de Báez, 1991. Yield and acceptability of eight fresh market tomato cultivars. J. Agric. Univ. P.R. 75(1): 93-95.

Fornaris, G., S. Martínez, E. Rosa and I. Cabrera, 2009. Proceso de evaluación en dos fases de cultivares de tomate de ensalada (Solanum lycopersicum L.) de 2003 a 2007. Informe del Proyecto H-094-S (unpublished)

Heuvelink, E. and M. Doris, 2005. Crop growth and yield. In: Heuvelink, E. (ed.) Tomatoes. Crop production science in horticulture 13, Cromwell Press, Trowbride. p.85114.

Hill, H., 2008. Food miles: Background and marketing. Appropriate Technology Transfer for Rural Areas (ATTRA). http://kirikiva.com/PDF/Foodmiles.pdf (viewed 13 July 2011)

Jacobsen, I., K. Abbott and A. Robson, 1992. External hyphae of vesicular arbuscular mycorrhizal fungi associated with Trifolium subterraneum L. Spread of hyphae and phosphorous inflow into roots. New Phytol. 120: 371-380.

Jones, B., 1999. Tomato plant culture. In the field, greenhouse, and home garden. CRC Press, Boca Raton, FL.

Juroszek, P., D. Ledesma, H. Ma, Y. Yang, M. Lumpkin, C. Lin, H. Tsai, L. Wu, M. Hanson, and C. Palada, 2008. Plant vigor and yields of organically and conventionally grown tomato crops in Taiwan. Acta Hortic. 767: 257-266.

Kaffka, S., D. Bryant, and F. Denison, 2005. Comparisons of organic and conventional maize and tomato cropping systems from a long-term experiment in California. http://orgprints.org/4384 (viewed 11 July 2011)

Lammerts van Bueren, E., 2002. Organic plant breeding and propagation: Concepts and strategies. $\mathrm{PhD}$ thesis, Wageningen University, the Netherlands.

Lammerts van Bueren, E., 2003. Challenging new concepts and strategies for organic plant breeding and propagation. Eucarpia Leafy Vegetables. p. 1-6. http://www. leafyvegetables.nl/downloads/04_017-022_Lammerts.pdf (viewed 29 June 2011)

Lammerts van Bueren, E., S. Jones, L. Tamm, K. Murphy, J. Myers, C. Leifert and M. Messmer, 2010. The need to breed crop varieties suitable for organic farming, using wheat, tomato and broccoli as examples: A review. Njas - Wageningen 
Journal Life Science. p. 1-13. http $/ /$ www.sciencedirect.com/science/article/pii/ S15735214000014X (viewed 6 July 2011)

Mendum, R. and L. Glenna, 2010. Socioeconomic obstacles to establishing a participatory plant breeding program for organic growers in the United States. Sustainability (2): 73-91. http://www.mdpi.com/journal/sustainability (viewed 19 August 2011)

Murphy, K., K. Campbell, S. Lyon and S. Jones, 2007. Evidence of varietal adaptation to organic farming systems. Field Crops Research (102): 172-177.

National Cooperative Soil Survey USA, 2006. Fraternidad series. http://FRATERNIDADSeries.webarchive (viewed 15 January 2010)

Palada, M. and A. Davis, 2001. Yield performance of tomato cultivars grown under organic management system. Proceedings of the Caribbean Food Crops Society 37: 154-160.

Pantoja, A., I. Cabrera, H. Bastidas and P. Stansly, 1999. Refuge crops enhance whitefly IPM. Biocontrol news and information 20(4):113-114.

Peet, M. and H. Willitis, 1995. Role of excess water in tomato fruit cracking. HortScience 30: 65-68.

Seminis, 2013. Seminis Performance Series sweet corn. http://www.seminis.com/global us/products/Pages/Sweet-Corn-Performance-Series.aspx (viewed 1 November 2013)

Sidhu, J. S. and S. Chellan, 2010. Genetic engineering of vegetable crops. P. 83-105. In: N.K. Sinha, Y. H. Hui, E. O. Evranuz, M. Siddiq and J. Ahmed (eds.) Handbook of vegetables and vegetable processing. Oxford Wiley-Blackwell.

Sullivan, P., 2004. Sustainable soil management. Soil systems guide. Appropriate Technology Transfer for Rural Areas (ATTRA). p. 22. http://www.soilandhealth.org/01agl ibrary/010117attrasoilmanual/010117attra.html (viewed 17 December 2010)

Vetiver Solutions Blog. 2010. Vetiver as windbreaker at Gargiulo Puerto Rico. http:// www.vetiversolutions.info Rico./2010/01/vetiver-as-windbreak-gargiulo-puerto.htm (viewed 5 July 2011)

Wessel-Beaver, L., G. Fornaris, A. Armstrong and E. Caraballo, 1990. Producción de tomate fuera de época. In: Memorias del foro técnico Cultivo, Producción y Elaboración de Tomate. Estación Experimental Agrícola, Universidad de Puerto Rico. p. 13-17. 